\title{
Kontribusi Ibu Rumah Tangga Dalam Meningkatkan Perekonomian Keluarga Melalui Berdagang Online Selama Pandemi Covid-19 di Kecamatan Sambas
}

\author{
U. Sulia Sukmawati \\ Institut Agama Islam Sultan Muhammad Syafiuddin Sambas \\ urai_suliasukmawati@yahoo.com
}

\begin{abstract}
Ahmad Yasir
Institut Agama Islam Sultan Muhammad Syafiuddin Sambas

yasirahmad200981@gmail.com
\end{abstract}

Neli

Institut Agama Islam Sultan Muhammad Syafiuddin Sambas

\begin{abstract}
This study aims to determine the level of housewives' contribution to the family economy and how housewives do online trading in an Islamic perspective. In this study using a qualitative approach, with a total of 30 respondents who resided in Sambas District, Sambas Regency. The results showed that most of the housewives contributed greatly to increasing family income, with a contribution rate of more than $30 \%$ as many as 19 people and during the pandemic the number of housewives who contributed more than 30\% decreased only around 17 people out of 30 respondents. The reason for housewives to trade online is mostly due to filling spare time and helping family income. Online trading carried out by housewives does not violate Islamic law, because online trading is carried out part time, so it does not leave its main obligation, namely as a wife and mother at home, and overall get permission from the husband. As for the Akad and transactions carried out by 30 respondents based on the principle of honesty, every product advertised on social media is described in detail
\end{abstract}

Keywords: $\quad$ Housewife, Income Contribution, Online Trading, Sambas

\section{PENDAHULUAN}

Pembangunan ekonomi suatu daerah tidak hanya dilihat dari modernisasi dalam masyarakat, tapi juga dilihat dari sektor perekonomiannya. Tinggi atau rendahnya perekonomian daerah tersebut, dapat dilihat dari pendapatan masyarakat di daerah tersebut. Semakin tinggi pendapatan rumah tangga di daerah tersebut, maka pertumbuhan ekonomi daerah itu tinggi. Salah satu sektor perekonomian saat ini berkembang yaitu sektor perdagangan memaluli fasilitas internet dan teknlogi informasi.

Perkembangan fasilitas internet dan teknologi informasi menyebabkan terbukanya ruang komunikasi dan kemudahan berinteraksi antar individu melalui media sosial. Berdasarkan hasil riset Wearesocial Hootsuite pada Bulan Januari 2019, pengguna media sosial di Indonesia mencapai 150 juta atau sebesar 56\% dari total populasi (databoks.katadata, 2019). Besarnya populasi pengguna internet dan telepon merupakan potensi bagi ekonomi digital nasional. Hal ini dapat dilihat begitu banyaknya. e-commerce, toko online dan bisnis lainnya berbasis internet di tanah air seperti facebook, twitter, dan lain-lain. 
Tren komunikasi melalui Media sosial semakin meluas hingga menyentuh hampir seluruh lapisan masyarakat dalam melakukan hubungan secara interaktif dengan sesama. Meluasnya penggunaan media sosial bahkan menjangkau berbagai kepentingan bisnis dalam memenuhi segala kebutuhan hidup. Hal ini membuat media sosial akhirnya masuk dalam bidang pemasaran produk, termasuk di dalamnya kegiatan berdagang secara online.

Berdagang online berpeluang besar dalam meningkatkan perekonomian, di mana pembeli online meningkat tiap tahunnya, tahun 2018 jumlah pembeli di Indonesia sekitar 11,9\% dari jumlah total populasi di Indonesia (Andi Donal Putera, 2019). Hal ini juga menggerakkan para Ibu Rumah Tangga yang ada di Kecamatan Sambas untuk berbisnis online mengingat jumlah penduduk Kecamatan Sambas yang cukup besar untuk dijadikan pangsa pasar dalam berbisnis online yaitu kurang lebih 52.024 jiwa, dengan jarak ratarata antar Desa di Kecamatan Sambas tidak terlalu jauh yaitu sekitar 3,8 km, jarak terdekat sekitar 0,3 km sedangkan jarak terjauh sekitar $12 \mathrm{~km}$ (BPS, 2020). Hal ini memudahkan antara penjual dan pembeli dalam melakukan transaksi di Media Sosail berbasis COD dengan barang yang tidak tahan lama.

Islam tidak melarang Ibu Rumah Tangga untuk mencari nafkah. Sebagaimana firman Allah swt (QS An-Nahal, 16:97)

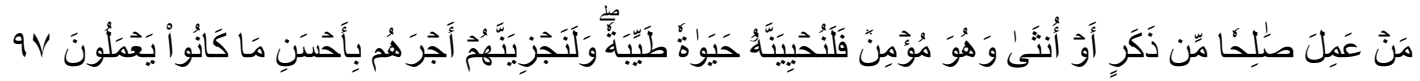

Barangsiapa yang mengerjakan amal saleh, baik laki-laki maupun perempuan dalam keadaan beriman, maka sesungguhnya akan Kami berikan kepadanya kehidupan yang baik dan sesungguhnya akan Kami beri balasan kepada mereka dengan pahala yang lebih baik dari apa yang telah mereka kerjakan

Ayat di atas menjelaskan bahwa laki-laki dan perempuan dalam Islam mendapat pahala yang sama dan amal kebaikan. Istri Rasulullah juga bekerja, salah satunya Siti Khatijah untuk kepentingan ekonomi. Islam tidak melarang perempuan bekerja dengan tujuantujuan positif.

Peran Ibu Rumah Tangga yaitu mengelola keuangan keluarga, untuk membangun kesejahteraan keluarga. Seorang istri harus memiliki trik, agar kesejahteraan dapat terwujud dengan memanfaatkan peluang dan kesempatan untuk menambah penghasilan tanpa harus meninggalkan rumah salah satunya dengan jualan online. Apalagi dengan berkembangnya dunia digital dan internet, tren bisnis sebagian besar beralih dari konvensional (offline) menjadi digital (online). Hal ini memudahkan para istri untuk menambah penghasilan keluarga melalui berdagang online. Kemudahan berdagang online mendorong para istri banyak melakukan fungsi ganda dalam rumah tangga. Selain itu dengan berdagang online dapat mengansah bakat dan hobi yang produktif.

Belakangan ini banyak perempuan yang bekerja sehingga berkontribusi dalam meningkatkan perekonomian keluarga baik melalui kegiatan bisnis menggunakan media sosial maupun bekerja di Pabrik-Pabrik dan Instansi. Penelitian mengenai kontribusi perempuan dalam menambah pendapatan, sudah banyak dilakukan diantaranya dalam Penelitian Nur Octoviyana Rahmah mengatakan bahwa di pendapatan yang dilakukan ibu rumah tangga berkontribusi lebih dari $30 \%$ terhadap pendapatan rumah tangganya. Hal 
ini menjelaskan bahwa pekerjaan yang mereka lakukan cukup memberikan tambahan penghasilan dalam membantu perekonomian keluarga. (Nur Octoviyana Rahmah, 2014). Selain itu dalam penelitian Marselina bahwa Ibu Rumah Tangga di Lampung Timur yang bekerja di PT. Great Giant Food berkontribusi cukup tinggi yaitu kurang lebih 34\% dalam perekonomian keluarga, walaupun pendapatan mereka rata-rata di bawah pendapatan suami (Prossiding Seminar Nasional dan call for paper, 2018).

Selan itu penelitian yang menyatakan media sosial sangat membantu dalam manmabah pendapatan diantaranya penelitian Sofia yang menyatakan bahwa EYP, NW dan YPS tidak lagi mendapatkan uang saku dari ayahnya dalam memenuhi kebutuhan sehari-hari dengan berbisnis online. Hasil bisnis online dapat mereka dapatkan sambil berkuliah dan bahkan ada yang ingin mengembalikan uang ayahnya (Sofia Eka Wahyu, 2014). Kemudian penelitian Helmalia bahwa pengaruh e-commerce dapat meningkatkan pendapatan UMKM binaan RKB BNI Kota Padang. Pengaruh ini dibuktikan dengan nilai signifikansi variabel e-commerce terhadap pendapatan UMKM binaan RKB BNI Kota Padang dengan nilai uji t kurang dari 0.05 (Helmalia dan Afrinawati: 2018).

Pada tahun 2020 ini dunia mengalami pandemi yang sangat bawa pengaruh terhadap perekonomian, termasuk kegiatan bisnis online. Di satu sisi, Covid-19menimbulkan economic shock, baik secara perorangan, rumah tangga, perusahaan mikro, menengah maupun besar, bahkan memengaruhi ekonomi negara. Menurut Badan Pusat Statistik 8 dari 10 perusahaan mengalami penurunan pendapatan selama pandemi, dikarenakan penurunan dalam permintaan (Badan Pusat Statistik, 2020). Akan tetapi, Pandemi Covid19di sisi lain meningkatkan pendapatan segelintir pelaku usaha semisal produk kesehatan, melalui penyesuaian platform bisnis berbasis online (Taufik dan Eka, 2020). Selain itu, akibat kebijakan physical distancing perilaku segelintir konsumen berubah dari konvensional menjadi digital. Dengan demikian, banyak masyarakat membeli kebutuhannya melalui sistem online atau memanfaatkan media sosial.

Menjamurnya pelaku bisnis online di media sosial saat ini, Badan Pusat Statistik mengungkapkan bahwa penggunaan Internenet dan Teknologi Informasi dalam pemasaran meningkat sekitar 5,76\% dilakukan oleh Penusaha baru. Dan tercatat juga bahwa peningkatan penggunaan internet dalam pemasaran meningkat tidak hany di Kota (sekitar 7.12\%), akan tetapi sampai di tingkat Kabupaten (kurang lebih 5,17\%) melakukan online untuk pemasaran saat Pandemi. Hal ini diungkapkan oleh Ibu Nia dimana sebelum pandemi tidak memiliki penghasilan, akan tetapi saat berlakunya fisical distancing, Ibu Nia mulai berjualan online sehingga mendapatkan penghasilan (Wawancara Ibu Nia, 2020). Sehingga pentingnya untuk melihat tingkat kontribusi Ibu Rumah Tangga berbisnis online dalam meningkatkan perekonomian keluarga di masa Pandemi Covid 19 saat ini.

\section{LANDASAN TEORI \\ 1. Bisnis Online}

Media sosial merupakan sebuah media online, dengan para penggunanya bisa dengan mudah berpartisipasi, berbagi, dan menciptakan isi meliputi blog, facebook, twitter, dan lain-lain. Meluasnya tren komunikasi di Indonesia melalui Media sosial, oleh berbagai lapisan masyarakat dalam melakukan hubungan secara interaktif dengan sesama. Bahkan menjangkau berbagai kepentingan bisnis dalam memenuhi segala kebutuhan hidup. Hal 
ini membuat media sosial akhirnya masuk dalam bidang marketing, termasuk di dalamnya kegiatan berbisnis secara online (R. Agus Baktiono, 2016).

Potensi Bisnis Online tidak dapat dipandang sebelah mata karena pada tahun 2018 digital ekonomi berkontribusi 5,5\% dari PDB Indonesia (CNBC Indonesia,2019). Bisnis online juga sangat berpotensi dilakukan mengingat jumlah penduduk Indonesia yang begitu banyak kurang lebih 265,4 juta, dengan jumlah pengguna media sosial aktif sekitar 130 juta (Bank Indonesia, 2020) kurang lebih 49,1\% dari total penduduk Indonesia. Adapun media sosial yang sering digunakan $84 \%$ whatshApp, $82 \%$ facebook, instagram $79 \%$, dan FB messenger 50\% (databoks, 2020). Tercatat bahwa pada tahun 2019 Indonesia merupakan negara yang memiliki nilai perekonomian digital terbesar di kawasan Asia Tenggara (Agatha Olivia, 2019)

Dalam dunia perdagangan di Indonesia, media sosial yang sering digunakan yaitu instagram dan facebook untuk mempromosikan bisnisnya. Pesatnya perdagangan berbasis media sosial dikarenakan beberapa faktor diantaranya semakin berkembangnya pemilik smatphone dan penetrasi internet. Di Asia Tenggara tahun 2018 pengguna sosial media hampir melampaui 1 miliar pengguna, naik 2 kali lipat dibandingkan tahun 2012 (Hari Widowati, 2018). Selain itu perdagangan melalui media sosial memiliki kemudahan bagi pelaku bisnis online untuk meraih komunitas lebih luas, di luar komunitasnya sendiri.

\section{Kontribusi Pendapatan Ibu Rumah Tangga Dalam Keluarga}

Kontribusi dalam kamus bahasa Indonesia memiliki arti sumbangan, dimana kontribusi pendapatan Ibu Rumah Tangga/Istri merupakan sumbangan pendapatan istri terhadap pendapatan total rumah tangga yang dirumuskan dalam persentase. Pendapatan rumah tangga merupakan pendapatan total antara pendapatan suami dan pendapatan istri. Keikutsertaan ibu rumah tangga dalam mencari uang, akan memengaruhi pendapatan keluarga dalam memenuhi kebutuhan keluarga. Pada umumnya peran istri secara ekonomi hanya menambah penghasilan keluarga dalam memenuhi kebutuhan. Ada beberapa faktor yang mendorong seorang istri untuk mencari tambahan penghasilan diantaranya (Fatimah Depi Susanti, 2013) :

a. Alasan Ekonomi, hal ini untuk menambah pendapatan keluarga (family income), yang dikarenakan kebanyakan pendapatan suami yang relatif kecil

b. Mengangkat status dirinya, agar memperoleh kekuasaan yang lebih besar di dalam keluarga.

c. Motif intrinsik yaitu untuk menunjukkan eksistensinya sebagai manusia yang mampu berprestasi di dalam keluarga maupun dalam kehidupan masyarakat.

\section{Hubungan COVID-19 Terhadap Perekonomian}

Corona Virus Diseases (Covid-19) diumumkan pada tanggal 30 Januari 2020 oleh word healt organization (WHO), bahwa virus tersebut mengancam kesehatan masyarakat secara global. Virus yang awalnya mengguncang Negara Cina, sekarang mengguncang seluruh dunia. WHO mengatakan bahwa dari 206 negara memiliki kematian lebih dari 40.000 orang. Hal ini membuat Pemerintah di setiap negara fokus untuk menangani kasus ini, dari mengobati sampai pencegahan, sehingga berdampak pada pengeluaran pemerintah dalam hal kesehatan semakin meningkat akan tetapi pendapatan Negara berkurang. Sebagian besar negara mengalami penurunan Pendapatan Domestik Bruto 
kurang lebih 3,9\%, sedangkan untuk negara berkembang kurang lebih 4\%-6,5\% (Word Healt Organzation, 2020) termasuk Negara Indonesia. Kondisi ini membuat Pekerjaan Rumah bagi Pemerintah dalam memulihkan perekonomian Negara.

Selama Pandemi pertumbuhan ekonomi mengalami perubahan, sebagian besar negara termasuk Indonesia mengalami resesi sampai kuartal ke III yaitu -2,9\% (Sri Muliyani, Kompas TV, 2020). Perekonomian di Indonesia mengalami penurunan dimana pada triwulan II pertumbuhan ekonomi mengalami penurunan sebesar 5,32\% (y-on-y) (Badan Pusat Statistik, 2020). Hampir semua sektor mengalami penurunan tidak hanya pada sektor ekspor, impor, dan pariwisata akan tetapi juga sangat berdampak pada sektor perdagangan. Hal ini ditambah Pemerintah menganjurkan untuk social distancing yang mengakibatkan masyarakat membatasi dirinya untuk berkativitas ke luar rumah. Covid19membawa dampak yang luar biasa pada masyarakat baik kalangan atas sampai bawah, terutama pada perekonomian. Banyak perusahaan yang bangkrut sehingga banyak karyawan yang di PHK. Selain itu Covid-19 membawa ketakutan yang luar biasa, Alquran menyebutkan dalam Surah Albaqarah ayat 155-156

"Dan sungguh akan Kami berikan cobaan kepadamu, dengan sedikit ketakutan, kelaparan, kekurangan harta, jiwa dan buah-buahan. Dan berikanlah berita gembira kepada orang-orang yang sabar (yaitu) orang-orang yang apabila ditimpa musibah, mereka mengucapkan: "Inna lillaahi wa innaa ilaihi raaji uun"

Pada ayat di atas sangat tepat apa yang dirasakan seluruh penduduk dunia saat ini, dimana seluruh penduduk dunia merasakan ketakutan yang luar biasa akibat dari Covid-19 ini. Masyarakat takut kehilangan harta karena adanya Covid-19, sebagian besar pendapatan masyarakat mengalami penurunan sehingga sulit dalam memenuhi kebutuhan hidup sehari-hari. Selain itu, masyarakat juga mengalami ketakutan kehilangan jiwa, karena virus Covid-19 dapat merenggut jiwa manusia.

Akibat Covid-19 yang dirasakan oleh Dunia, sehingga negara-negara yang tergabung dalam G30 mengadakan pertemuan yang bertemakan Realizing The Oppotunity of the 21st Century di Arab Saudi. Latar belakang dari pertemuan tersebut, mengubah tatanan perekonomian menuju ekonomi keuangan dan digital, agar para UMKM, perempuan dan pemuda dapat memanfaatkan teknologi digital dalam melakukan aktivitas ekonomi (Dito Aditia Darma Nasution, dkk, 2020). Menurut Siti Ngainnur Rohmah mengatakan bahwa bisnis yang berpeluang besar saat Pandemi adalah menggunakan Sosial Media dengan menggunakan jasa go food/grab food atau sejenisnya (Sitti Ngainnur Rohmah, 2020). Badan Pusat Statistik (BPS) menyatakan bahwa untuk mempertahankan pendapatan bagi para pengusaha harus dengan memanfaatkan internet dan teknologi informasi (TI). Dari penelitian pihak BPS ada kenaikan penggunaan internet selama Pandemi kurang lebih $5,76 \%$ perusahaan baru menggunakan internet dan Ieknologi Informasi untuk pemasaran.

\section{METODOLOGI PENELITIAN}

Penelitian ini menggunakan pendekatan kualitatif yang berlandaskan pada filsafat positivisme yaitu penelitian kualitatif dengan data kuantitatif (Sugiono, 2017). Jenis penelitian ini merupakan penelitian lapangan (field Research) yaitu penelitian yang di lakukan di lapangan atau lokasi penelitian dalam kancah sebenarnya. Penelitian field 
research dimana data diperoleh dari lapangan secara langsung dari sumbernya. (Sugiono, 2017). Teknik pengumpulan informan dengan purposive sampling karena informan ditetapkan dengan sengaja, yaitu ibu rumah tangga yag tidak bekerja di Kantoran, berjualan online dan seorang muslim.

Data adalah kumpulan informasi atau fakta yang diperoleh melalui proses penelitian dan bisa dianalisis dalam rangka memahami permasalahan penelitian. Sedangkan sumber data merupakan subyek dari mana data-data penelitian bisa diperoleh Sumber data merupakan subjek dari mana data-data penelitian bisa diperoleh (Adnan Mahdi dan Mujahidin, 2014). Sumber data yang menjadi rujukan dalam penelitian ini yaitu: data primer berupa hasil wawancara dari responden dan data sekunder berupa Jumlah penduduk di Kecamatan Sambas diperoleh dari Data Badan Pusat Statistik.

Setting penelitian adalah hal-hal yang berkaitan dengan lingkungan, tempat atau wilayah yang akan dijadikan lokasi atau obyek penelitian (Adnan Mahdi dan Mujahidin, 2014). Tempat penelitian ini di Kecamatan Sambas, tempat ini diambil dikarenakan terletak di pusat Kota Kabupaten Sambas. Adapun waktu penelitian ini yaitu tahun 2020 dan dilakukan penelitian dalam satu waktu kurang lebih 1 bulan. Dalam mengumpulkan data yang diperlukan untuk mengungkapkan masalah yang terdapat pada bagian awal penelitian ini digunakan ada beberapa teknik yaitu:

a. Observasi

Observasi adalah instrument lain yang sering di jumpai dalam penelitian. Observasi yaitu pengamatan yang dilakukan secara sengaja, sistematis mengenai fenomena sosial dengan gejala-gejala psikis kemudian dilakukan pencatatan. Dalam obsevasi ini, peneliti lebih banyak menggunakan salah satu panca indranya yaitu indra penglihatan dan juga pendengaran. Instrument observasi akan lebih efektif jika informasi yang hendak di ambil berupa fakta alami, tingkah laku dan hasil kerja responden dalam situasi alami (Slamed Riyadi, 2016).

b. Wawancara

Wawancara adalah menanyakan sesuatu yang di rencanakan sebelumnya oleh peneliti kepada responden dan hasilnya di catat sebagai informasi penting dalam sebuah penelitian. Wawancara yang diarahkan pada suatu masalah tertentu atau yang menjadi pusat penelitian. Ini merupakan sebuah proses untuk menggali informasi secara langsung dan mendalam sebagai data primer. Wawancara mendalam ini dilakukan dengan informan yang dianggap memiliki representasi informasi yang relevan dengan penelitian (Slamed Riyadi, 2016).

c. Dokumentasi

Dokumentasi adalah salah satu cara untuk pengumpulan data melalui profil tertulis yang berupa arsip yang berhubungan dengan masalah penelitian. Teknik dokumentasi di gunakan untuk melengkapi data yang telah ada.

Analisis data dalam penelitian dengan mendeskriptifkan, mengkategorisasi dan mengkoneksi data penelitian. Dapat digambarkan sebagai berikut: 


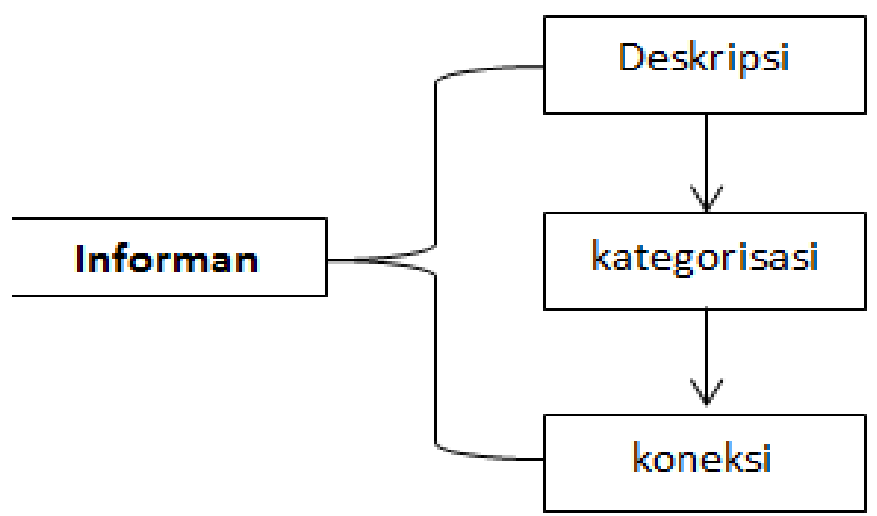

Gambar 1. Analisis metode kualiatatif

Langkah pertama dengan melakukan mendiskripsian informan, dengan memilih data yang penting dari informan, melalui teknik pengumpulan data yaitu wawancara. Langkah kedua melakukan kategorisasi dengan rumus persentase (Sugiyono, 2017). Dengan rumus di bawah ini (Nur Octoviyana Rahmah, 2014),

$$
\text { Kontribusi pendapatan istri }=\frac{\text { pendapatan istri onlineshop }}{\text { pendapatan total keluarga }} \times 100 \%
$$

Kriteria pengukurannya adalah :

a. Apabila kontribusi pendapatan wanita terhadap pendapatan keluarga diatas $30 \%$ maka kontribusi pendapatan wanita cukup tinggi.

b. Apabila kontribusi pendapatan wanita terhadap pendapatan keluarga dibawah $30 \%$ maka konribusi pendapatan wanita cukup rendah.

Langkah terakhir connection dengan melakuakan analisis yang mendalam terhadap data dan informasi yang diperoleh, sehingga menjadi suatu bangunan pengetahuan dan ilmu yang baru (Sugiyono, 2017).

\section{HASIL DAN PEMBAHASAN \\ 1. Media Sosial yang digunakan oleh Ibu Rumah Tangga dalam berdagang online}

Salah satu keuntungan menggunakan internet yaitu sebagai media perdagangan. hal ini mendapat respon positif dari masyarakat dan pelaku Pedagang online dikarenakan bertransaksi online ini dianggap mudah, cepat, praktis, dan dapat meminimalisir pengeluaran untuk mendapatkan keuntungan yang maksimal. Selain itu bahwa dengan menjual lewat internet selain bisa mendapatkan uang, dari segi agama bisa menjalin silaturahmi karena langsung diantar kerumah pelanggan. Besarnya populasi pengguna internet dan telepon merupakan potensi bagi ekonomi digital nasional. Alhasil, muncul e-commerce, transportasi online, toko online dan bisnis lainnya berbasis internet di tanah air. Hal ini akan menjadi kekuatan ekonomi digital di kawasan Asia Tenggara.

Kemudahan dalam penggunaan internet inilah yang menjadi alasan banyak Ibu Rumah Tangga berdagang melalui media sosial. Sebagimana penuturan Yulisa bahwa melakukan penjualan melalui media sosial memiliki beberapa manfaat yang dapat dilihat dari berbagai macam aspek. Diantaranya dari aspek materil, dengan berjualan kita akan mendaptakan income dan profit. Dilihat dari aspek agama, bisa menjalin silaturahmi karena langsung diantar ke rumah pembeli. Dari aspek sosial, semakin banyak teman dan dari segi geografis, bisa lebih mengenal daerah Sambas dan sekitarnya (Yulisa, 2019). 
Dalam penelitian ini, 30 responden mengatakan bahwa berdagang online bertujuan untuk menyalurkan hobi dan membantu perekonomian keluarga dengan mudah.

Adapun media sosial yang sering digunakan saat melakukan transkasi yaitu facebook, mesenger, whatsApp dan Instagram dapat dilhat pada tabel berikut ini:

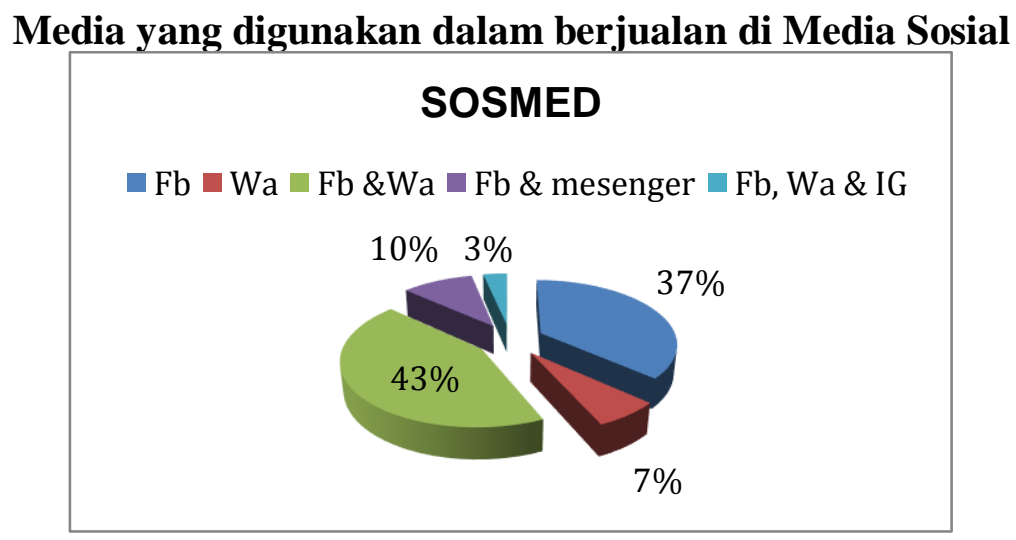

Gambar 2, data primer dikelola

Dari gambar di atas secara keseluruhan responden menggunakan facebook sekitar $90 \%$ hanya beberapa yang menggunakan whattshap, Mesenger dan Instagram. Secara rinci sekitar 37\% informan yang hanya menggunakan facebook, $43 \%$ menggunakan FB dan WA, $10 \%$ menggunakan $\mathrm{Fb}$ dan mesenger, $7 \%$ hanya WA, dan 3\% yang menggunakan ketiga media sosial dalam melakukan bisnis online. Facebook bagi informan memiliki kemudahan tersendiri untuk mengiklankan produk, karena cakupannya lebih luas dibanding dengan whatsApp, selain itu sangat mudah dan gampang menggunakannya.

\section{Kontribusi Ibu Rumah Tangga dalam Perekonomian Keluarga Sebelum Pandemi}

Pertumbuhan ekonomi suatu daerah dapat dilihat dari sektor perekonomiannya. Tinggi atau rendah perekonomian daerah tersebut salah satunya dipengaruhi oleh pendapatan masyarakat di daerah tersebut. Semakin tinggi pendapatan rumah tangga di daerah tersebut, maka pertumbhan ekonomi daerah tersebut tinggi. Pendapatan rumah tangga merupakan pendapatan total antara pendapatan suami dan pendapatan istri. Keikutsertaan ibu rumah tangga dalam mencari uang, akan memengaruhi pendapatan keluarga dalam memenuhi kebutuhan keluarga.

Binsis online yang responden tekuni dilakukan secara part time, bisnis tersebut mereka lakukan hanya mengisi waktu luang sebagai pekerjaan sampingan disamping pekerjaan utama sebagai Ibu Rumah Tangga. Waktu luang mereka gunakan untuk melayani berbagai pertanyaan dari calon pembeli terhadap barang yang dipromosikan di media sosial. Selain itu mengantarkan barang yang dibeli oleh pembeli. Adapun pendapatan yang dihasilkan dari para Ibu Rumah Tangga ini, sebagian besar digunakan untuk memenuhi kebutuhan sehari-hari, modal dan menabung untuk keperluan pendidikan anak. Besarnya kontribusi yang dilakukan responden dalam perekonomian keluarga dapat dilihat di bawah ini: 


\section{Tingkat Kontribusi Ibu Rumah Tangga dalam Pendapatan Rumah Tangga sebelum Pandemi}

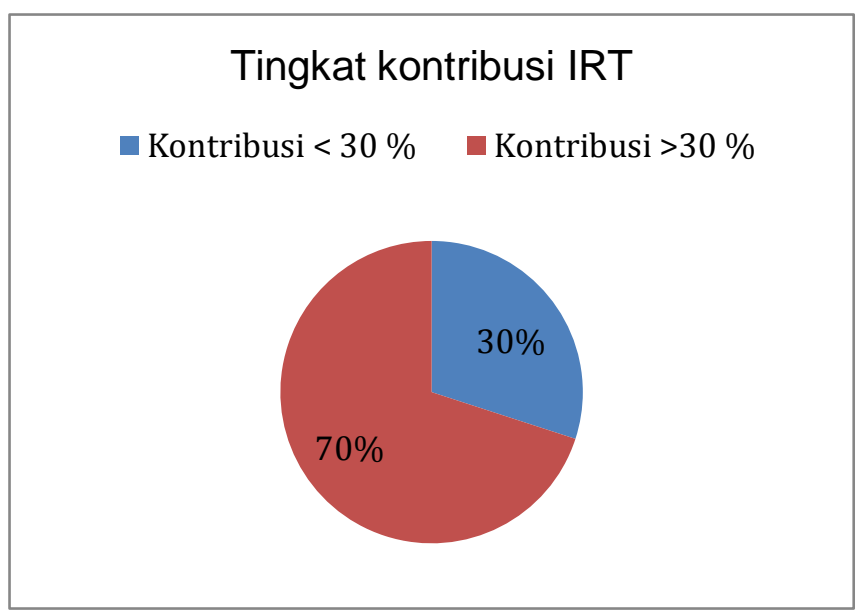

Gambar 3. Data dikelola

Dari gambar 3 menjelaskan bahwa 21 responden atau kurang lebih 70\% kontribusi Ibu Rumah Tangga dalam perekonomian keluarga melebihi $30 \%$ dari pendapatan total keluarganya. Rata- rata penghasilan dari responden ini sebesar Rp 3.110.526 /bulan. Upaya dalam keluarga, ibu rumah tangga sangat membantu dalam meningkatkan kesejahteraan melalui bisnis online, tanpa menganggu peran utamanya dalam keluarga, dan tanpa menggunakan waktu yang banyak untuk meninggalkan rumah, selain itu anak tetap terawasi di rumah. Sebagian besar responden memiliki kontribusi melebihi $30 \%$ dikarenakan mereka melakukan bisnis online untuk membantu perekonomian keluarga, sehingga mereka seirus dan rutin melakukan bisnis online melalui media sosial.

Dari 30 responden hanya 11 responden saja yang berkontribusi rendah yaitu sekitar 4$17 \%$ dari jumlah total pendapatan keluarganya. dikarenakan melakukannya hanya berdasarkan keinginan semata, bukan sebuah tuntutan dalam keluarga, sehingga melakukan bisnis online hanya menggunakan waktu luang saja. Walaupun demikian sangat bermanfaat sekali bagi ibu rumah tangga bisa memanfaatkan waktu luangnya dengan hal yang produktif, apalagi bisa menghasilkan pendapatan.

\section{Kontribusi Ibu Rumah Tangga dalam Perekonomian Keluarga Selama Pandemi}

Saat ini dunia mengalami keguncangan ekonomi dikarenakan adana COVID-19, banyak perusahaan yang mengalami penurunan pendapatan akan tetapi ada perusahaan baru yang muncul disaat pandemi. Adanya pandemi ini menjadi sebuah masalah baru bagi pebisnis. Karena problem ini tidak hanya menimbulkan kecemasan di bidang kesehatan tetapi juga bidang-bidang lain terutama bidang ekonomi. Pandemi dapat menimbulkan economic shock, yang memengaruhi perekonomian baik secara perorangan, rumah tangga, perusahaan mikro, menengah maupun besar, bahkan memengaruhi ekonomi negara. Tidak tutup kemungkinan Pandemi ini juga dirasakan oleh para Ibu Rumah Tangga yang berjualan online. Tingkat kontribusi 30 responden dalam perekonomian keluarga saat pandemi dapat dilihat pada tabel berikut ini: 


\section{Tingkat Kontribusi Ibu Rumah Tangga dalam Pendapatan Rumah Tangga selama Pandemi}

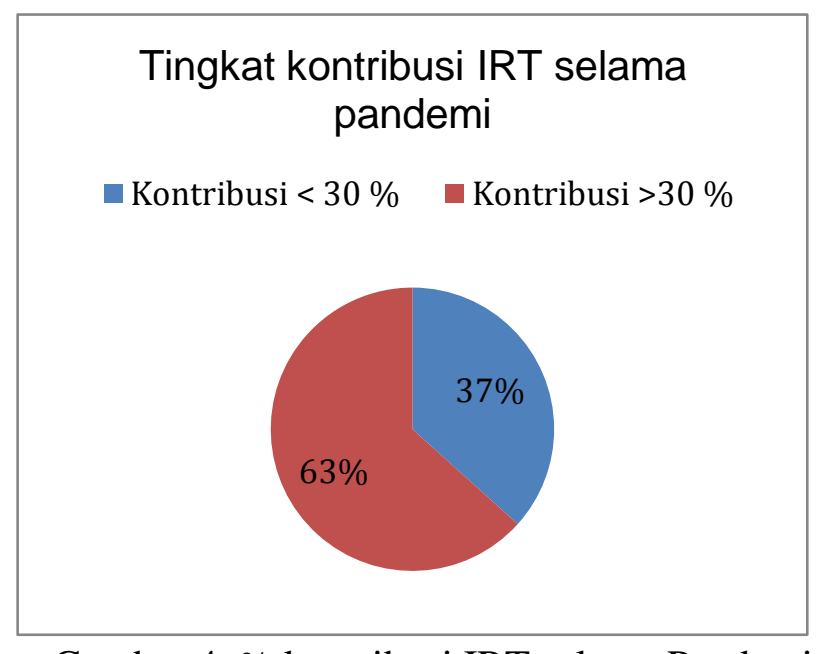

Gambar 4. \% kontribusi IRT selama Pandemi

Dari gambar 4 menunjukkan tingkat kontribusi Ibu Rumah Tangga dalam perekonomian keluarga selama pandemi menurun jumlahnya hanya 17 orang yang melebihi $30 \%$ dari pendapatan total keluarga, dimana sebelum Pandemi berjumlah 19 orang yang berkontribusi melebihi $30 \%$ dari pendapatan total keluarga. Rata- rata penghasilan dari 18 responden ini sebesar Rp Rp2.300.000,00 /bulan, sedangkan 12 responden yang berkontribusi rendah yaitu sekitar 6-23\% dari jumlah total pendapatan keluarganya ratarata penghasilan kurang lebih Rp595.833,33. Selain itu perubahan pendapatan Ibu Rumah Tangga yang berkontribusi dalam perekonomian keluarga disaat Pandemi dapat dilihat pada tabel berikut ini:

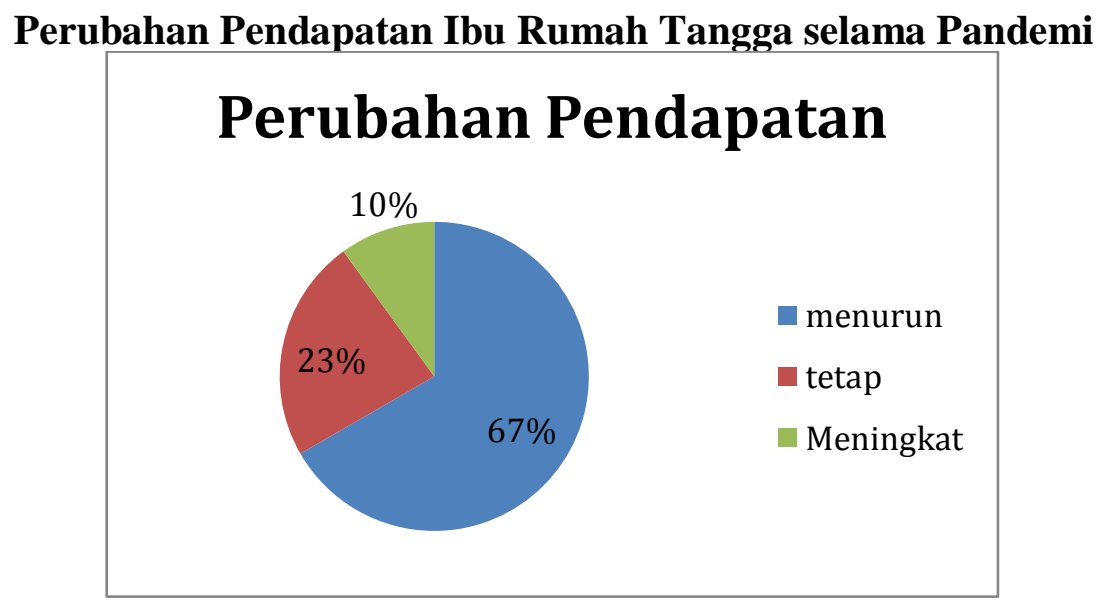

Gambar 5 data primer yang diolah

Dari tabel 5 menunjukkan bahwa dari 30 responden yang mengalami penurunan pendapatan penghasilan sekitar 20 orang berarti sekitar $66,7 \%$, yang sebagian besar dialami produk kuliner, hal ini dikarenakan dimasa pandemi orang-orang jarang belanja, masyarakat lebih aman kalau mereka membuat makanan sendiri dari pada memakan buatan orang lain. Selain itu masyarakat enggan terlalu banyak mengeluarkan untuk halhal yang tidak terlalu penting, karena masa pandemi banyak yang melakukan 
penghematan dikarenakan pendapatan seluruh masarakat berkurang. Alasan selanjutnya pendapatan mengalami penurunan karena memang mengurangi aktivitas keluar dimasa pandemi termasuk jualan online, karena jika jualan online maka akan keluar rumah utuk mengantar pesanan. Hal ini dikarenakan di Sambas belum masuk jasa pengantaran seperti GO GRAB maupun GO JEK. Akan tetapi ada responden yang mengalami kenaikan sekitar 1 orang dari seluruh responden, dan 3 orang pendapatan dari penjualan makanannya tetap tidak mengalami perubuhan baik sebelum maupun sesudah pandemi.

Pendapatan ibu rumah tangga yang tidak mengalami perubahan selama pandemi yaitu ibu rumah tangga yang berjualan online alat-alat kecantikan, dimana alat-alat kecantikan merupakan kebutuhan wanita yang tidak bisa digantikan dengan yang lain, sehingga pendapatan produk ini tidak mengalami perubahan yang signifikan, begitu juga dengan penjual produk perabot rumah tangga.

\section{KESIMPULAN}

Adapun kesimpulan dalam penelitian ini, bahwa sebelum pandemi Ibu Rumah Tangga memiliki kontribusi dalam perekonomian keluarga yang melebihi 30\% sebanyak 19 responden dari 30 responden. Hal ini menunjukkan bahwa walaupun seorang Ibu Rumah Tangga ang aktivitasnya hanya di rumah, akan tetapi bisa membantu perekonomian keluarga yang sangat besar. Akan tetapi pada saat Pandemi Covid-19 menyerang di Kota Sambas, Ibu Rumah Tangga yang berkontribusi dalam pendapatan keluarga berkurang menjadi 17 responden dari 30 responden. Hal ini dikarenakan banyak pembeli enggan membelanjakan uangnya, dikarenakan takut untuk berinteraksi dengan masyarakat luar, sehingga usaha yang dilakukan Ibu Rumah Tangga mengalami penurunan.

\section{DAFTAR PUSTAKA}

Badan Pusat Statistik, “ Kecamatan Sambas dalam Angka 2019”, https://sambaskab.bps.go.id/, diakses 24 Agustus 2020.

2020”, 5 Agustus Tahun 2020,

Baktiono, R.Agus 2016. Putu Artaya, Memilih Media Sosial Sebagai Sarana Bisnis Online Melalui Pendekatan Uji Categorical, e-Jurnal Manajemen Kinerja .EISSN: 2407-7305, vol 2, no 2.

CNBC Indonesia,2019

Donal Andri Putera, "Jumlah Pembeli "Online" Indonesia Capai 11,9 Persen dari Populasi”, https://ekonomi.kompas.com/, diakses 24 Agustus 2020.

Hanum Septi Latifa, Peran Ibu Rumah Tangga dalam Membangun Kesejahteraan Keluarga, dalam Jurnal Academica Vol. 1 No. 2. Juli- Desember Tahun 2017

Helmalia dan Afrinawati, dengan judul "Pengaruh E-Commerce terhadap Peningkatan Pendapatan Usaha Mikro Kecil dan Menengah di Kota Padang” JEBI (Jurnal 
Ekonomi dan Bisnis Islam) - Volume 3, Nomor 2, Juli - Desember 2018, Journal. Febi.uinib.ac.id. diakses 22 Juli 2020.

https://databoks.katadata.co.id/datapublish/2019/02/08/berapa-pengguna-media-sosial indonesia

Kaelan, M.s, Metodologi Penelitian Kualitatif Bidang Filsafat, (Yogyakarta: Paradigma, 2005). hlm. 58.

Kusumaning Dyah Purbasari, Putri Sri Lestari. 2015. Pembagian Peran Dalam Rumah Tangga Pada Pasangan Suami Istri Jawa: Jurnal Penelitian Humaniora, Vol. 16, No. 1.

Lestari Nurwani, Peran dan Kontribusi Perempuan dalam meningkta kan pendapatan keluarga menurut perspektif islam di desa teluk pekedai satu Kecamatan Teluk Pekedai Kabupaten Kubu Raya, dalam Jurnal Curvanomic Vol. 7 No. 2 Tahun 2018.

Marselina dkk, (2018), Pengabdian Kepada Masarakat Melalui Diseminasi Hasil Penelitian Terapan, Prossiding Seminar Nasional dan caal for paper, Penerbit : FEB Universitas Lampung.

Mahdi Adnan dan Mujahid, 2014 Panduan Penelitian Praktis untuk Menyusun Skripsi.Tesis Disertasi, Bandung: Alfabeta Pratiwi Sofia Eka Wahyu, Dkk, 2014. Motivasi Berbisnis Online Pada Mahasiswa Program Studi Pendidikan Ekonomi Fakultas Keguruan Dan Ilmu Pendidikan Universitas Jember, Artikel Ilmiah Mahasiswa. Vol 1 no 1.

Nasution, Dito Aditia Darma dkk, "Dampak Pandemi COVID-19Terhadap Perekonmian Indonesia", jurnal Benefita, vol 5, no 2 2020, www.researchgate.net, diakses 9 oktober 2020

Susanti, Fatimah Depi, (2013).“ Kontribusi Perempuan Parengge-rengge dalam Ekonomi Keluarga”, Sosial Budaya, Vol 10 No 01. Diakses 2 Oktober 2020.

Taufik Dan Eka Avianty, "Dampak Pandemi Covid-19Terhadap Binis Dan Eksistensi Platform Online", Jurnal Pengembangan Wiraswasta Vol. 22 No. 01 - Apr 2020, Http://Ejurnal.Stieipwija.Ac.Id/, Diakses 15 Oktober 2020.

Victoria, Agatha Olivia (2019), "Sri Mulyani: Ekonomi Digital RI Tercepat di Asia, Bernilai Rp 1.820T,” katadata.co.id, diakses 30 Oktober 2020.

Widowati, Haris (2018), "Pedagang Indonesia Paling Banyak Manfaatkan Instagram dan Facebook", https://katadata.co.id, diakses 29 Oktober 2020. 